\title{
Elephant corridors in India: lessons for other elephant range countries
}

\author{
A. J. T. Johnsingh and A. Christy Williams
}

\begin{abstract}
The conservation status of five elephant corridors in different regions of India is discussed. Elephants have not used the 13-km-wide corridor between Ariankavu and Thenmalai, in the southern portion of the Western Ghats for several decades because a rail track and road, both of which are bordered by human habitations, cross it. The future of the Chilla-Motichur and Rajaji-Corbett corridors, which hold the RajajiCorbett elephant population in north-west India as one entity, is bleak. It is still possible for elephants to use the Kallar-Jaccanari corridor linking the 4000-strong elephant population of northern and southern Nilgiri Biosphere Reserve in southern India. It may be possible to save the Siju-Rewak corridor, which connects the
\end{abstract}

\section{Introduction}

The habitat of the Asian elephant Elephas maximus in India and elsewhere is being fragmented into smaller areas as a result of developmental activities. This has caused much concern, given that the equilibrium theory of island biogeography (MacArthur \& Wilson, 1967) predicts that the size of the habitat island a species occupies plays an important role in the survival of that species. Larger areas may contain more individuals of a particular species than smaller areas and, therefore, offer the species a greater chance of persistence over time. In order to ameliorate the effects of habitat fragmentation, the idea of using habitat corridors was introduced first, in 1959, in Sri Lanka (Anon., 1959) but was only later taken up by the scientific community because of the interest in the theory of island biogeography. Diamond (1975) proposed the creation of corridors, by protecting strips of forests connecting two larger habitat islands. Corridors aid dispersal and movement of individuals between habitat islands, thus enlarging effective population sizes and in turn decreasing extinction probabilities. They also provide animals with access to habitats that would otherwise be denied to them. As far as elephants are concerned, the disadvan-

A. J. T. Johnsingh (corresponding author) and

A. Christy Williams Wildlife Institute of India, PO Box 18 ,

Dehra Dun-248 001, India. E-mail: ajtjohnsingh@wii.gov.in

Received 14 January 1998. Accepted 15 October 1998 elephant populations on either side of the River Simsang in north-east India. The authors suggest that other Asian countries that have elephant populations and that are capable of establishing large conservation units, should have master plans that should detail possible developmental activities around existing wildlife habitats. Establishing vast protected areas for large mammals, however, would need political will and regular communication among the nations' development planners, wildlife managers and researchers.

Keywords Asian elephant, developmental activities, Elephas maximus, habitat fragmentation, wildlife corridors. tage of corridors is that they may increase the interface between elephants and humans, thus leading to elephant-human conflict. Careful planning and serious efforts are needed to mitigate such conflicts around corridor areas. However, keeping in mind the longterm conservation benefits that would accrue to the species, the necessary efforts would be worthwhile.

\section{Elephant corridors in India}

As a result of increased awareness of the advantages of corridors and the need to ensure the survival of largebodied mammals such as elephants, a network of protected areas connected by corridors was proposed as a conservation strategy in India (Rodgers \& Panwar, 1988; Sukumar, 1991). This resulted in identifying and declaring several elephant corridors (e.g. Johnsingh et al., 1990, 1991; Sunderraj et al., 1995; Williams \& Johnsingh, 1997). In this paper, the conservation status of five elephant corridors in India is presented and discussed. Over the years, some of these corridors have lost their effectiveness as a result of developmental activities, as is already happening or could happen in other potential elephant corridors in Asia. It is our belief that the lessons we have learnt in trying to conserve these corridors would be useful to other Asian nations that have sizeable Asian elephant populations and are in a phase of rapid development.

All the corridors under discussion (Fig. 1) are narrow strips of forest connecting two larger forest areas. The senior author (A.J.T.J) has been associated with the 
conservation efforts of all the corridors under discussion. All elephant population figures are from Sukumar (1991).

\section{Ariankavu Pass in Tamil Nadu and Kerala}

A 13-km-wide corridor stretches across a pass between Ariankavu and Thenmalai in Tamil Nadu and Kerala in the southern portion of the Western Ghats. It once connected the elephant population of Periyar Tiger Reserve (c.700-900 elephants) to the north of the pass and the elephants from the Ashambu hills (c. 150-200 elephants) to the south. The corridor is partly encroached government forest land and partly government-owned revenue land. A railway line and a road, running east to west through the corridor, were built around 80 years ago. The mother of A.J.T.J. remembers seeing elephants along the railway tracks $60-70$ years ago. A survey in 1988 found no signs nor received reports of elephants using this corridor (Johnsingh et al., 1991). This is due mainly to human encroachment, in the form of plantations of banana Musa paradisiaca, cardamom Elettaria cardamom, pepper Piper nigrum and rubber Hevea brasiliensis, and human settlements, largely along the northern side of the corridor. Elephants no longer use this corridor.

\section{The Chilla-Motichur corridor in Uttar Pradesh}

The Chilla-Motichur corridor in Uttar Pradesh is one of two (the other being the Rajaji-Corbett corridor) that maintain the Rajaji-Corbett elephant population as one entity. This population forms 90 per cent of the $750-$ 1000 elephants in north-west India (Johnsingh \& Joshua, 1994; Singh, 1995). The corridor is approximately $3 \mathrm{~km}$ long and $1 \mathrm{~km}$ wide, and lies across the River Ganges, which flows between the eastern and western half of the park. Fragmentation of the park into eastern (c. 200 elephants) and western (c. 400-500 elephants) portions has occurred as the result of the building of the Hindustan Antibiotic Factory, establishing the Raiwala Army Camp and an ammunition dump,

Fig. 1 Elephant range (areas with solid shading) and five elephant corridors in India.

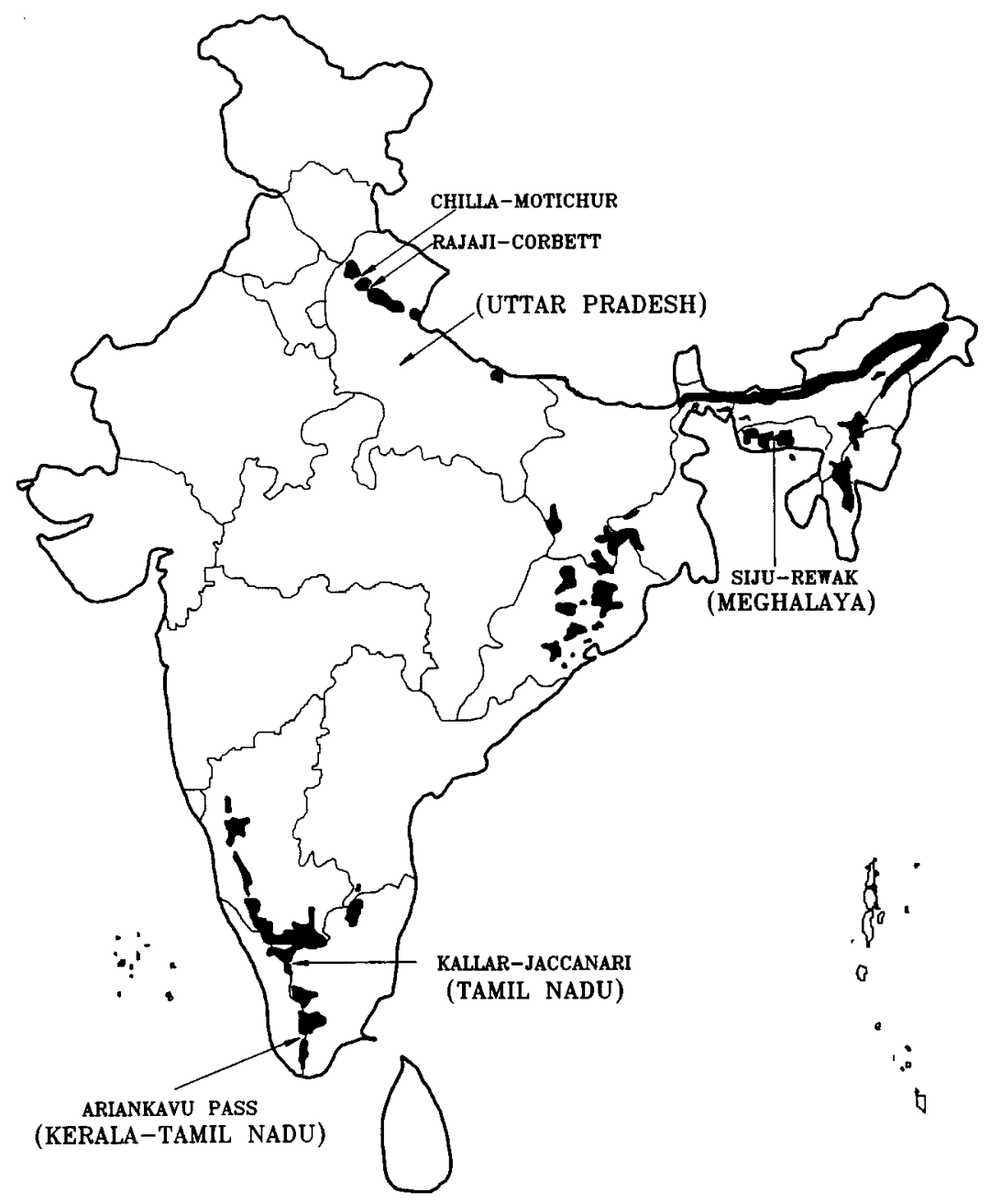


and settling evacuees from the submersion area of Tehri Dam village in the corridor area (Johnsingh et al., 1990). Ownership of the corridor land is shared by the Forest Department, Army and the Tehri Dam evacuees. The building of the 14-km-long Kunaun-Chilla power channel in the 1970s rendered the corridor almost unusable The channel is $22 \mathrm{~m}$ wide and, at full capacity, $9 \mathrm{~m}$ deep. The sides of the channel are set at $45^{\circ}$ and are cemented, except for a $500-\mathrm{m}$ length, and therefore do not offer foot-hold to elephants. After this channel was built, the female groups stopped using the corridor and now only the bulls cross the channel at three places. The movement of bulls has fortunately helped in continuing the genetic flow between the elephant populations on either side of the river (Johnsingh et al., 1990).

A state highway and a railway line also bisect the corridor. The volume of traffic along the highway is very large and trains ply across the corridor at least 24 times a day. Several elephants have been injured or killed by trains. Despite the corridor having been identified in the early 1980s, its conservation status has been in constant decline (Johnsingh et al., 1990; Johnsingh, 1992). Hundreds of cattle and people range in the corridor area daily to meet fodder and fuelwood requirements. The apathy of the Uttar Pradesh Government has led to the failure to establish this corridor despite an offer of financial assistance of \$US280,000 (Rs10 million) by the Government of India's Project Elephant, in 1996-97. On four islands in the Ganges, which form a vital link in the corridor area, important elephant food plants are disappearing and being replaced by unpalatable introduced species (Johnsingh et al., 1990). The future of this corridor is bleak.

\section{The Rajaji-Corbett corridor in Uttar Pradesh}

The corridor connecting the Rajaji National Park (c. 600-700 elephants) with the Corbett National Park (c. 300-400 elephants) lies across the Koh River in the Lansdowne Forest Division. It is the second of the two corridors that still hold the Rajaji-Corbett elephant population as a single entity. The movement of elephants has been restricted across this corridor as a result of the building of the Kotdwar-Lansdowne road parallel to the Koh River. This has resulted in steep edges, which, together with the walls built to prevent landslides, impede crossing by elephants (Sunderraj et al., 1995). This hilly corridor is used only by bulls. Cows possibly stopped moving from the Rajaji forests to the Corbett forests when the extensive forests on the southern side of the hilly terrain were cleared for agriculture and human settlements, possibly at the beginning of the century (Sunderraj et al., 1995). The corridor is beset with numerous problems because of intensive human dependency on this area for daily fuel and fodder requirements. Sunderraj et al. (1995) concluded that steep terrain and biotic pressures deter cow groups from using the corridor area. They feared that the bulls would also stop using the corridor unless the current level of human dependency on the corridor forests was reduced.

\section{The Kallar-Jaccanari corridor in Tamil Nadu}

The Kallar-Jaccanari corridor in Tamil Nadu is situated in the Nilgiri Biosphere Reserve (NBR) in southern India, which contains the single largest population of Asian elephants (c. 4500). It serves as a link between the elephant populations of the northern NBR (c. 4000 elephants) and the southern NBR (c.500 elephants; Davidar, 1982; Ramakrishnan \& Sivaganesan, 1997). About $7 \mathrm{~km}$ long and varying in width between 0.5 and $3 \mathrm{~km}$, it is bounded on the north by steep hills and to the south by agricultural fields and arecanut plantations. At its narrowest point the corridor passes through private forests on the southern boundary. A residential school was built in this area in 1995-97. This led to a loss of about $17.4 \mathrm{ha}$, which has reduced the corridor area considerably. Added to this is the high level of human dependence on the corridor forest area as a result of fuelwood collection by local villagers (Ramakrishnan \& Sivaganesan, 1997). However, the school authorities accepted in principle the recommendations made after an ecological impact assessment of the school on the corridor was carried out (Ramakrishnan \& Sivaganesan, 1997). These included increasing the corridor width by moving the electric fence that runs east to west on the northern side, establishing a plantation to act as a buffer zone, and curtailing all activities that would impede the movement of elephants and other animals along the boundary adjacent to the corridor area. However, to date (September 1998) the electric fence had not been moved as agreed.

\section{The Siju-Rewak corridor in Meghalaya}

The Siju-Rewak corridor in the state of Meghalaya in north-east India connects a population of 600 elephants in and around Balphakram National Park with another population of 250 elephants across the River Simsang. It is about $3.5 \mathrm{~km}$ long and $2 \mathrm{~km}$ wide (Williams \& Johnsingh, 1997). Elephants can cross only in three or four places where there are sandy stretches along the river; elsewhere the river is bounded by steep limestone cliffs and large boulder formations along both banks. Only a part of the corridor forest is controlled by the Forest Department; the rest is under local tribal community management. The tribal authorities have leased 
out an area of $2 \mathrm{sq} \mathrm{km}$ in the corridor area to a private company for mining limestone and to set up a factory to manufacture cement from the mined limestone. However, after the discovery of the mining survey camps during a status survey of elephants in this area (Williams \& Johnsingh, 1997), a public interest litigation has been filed in the Supreme Court of India to stop the mining project from going ahead, and an effort is also being made to acquire the parts of the corridor area that are private forests.

\section{Discussion}

The ideas of using corridors to ameliorate the effects of habitat fragmentation were being developed elsewhere during a time when the Indian government was sanctioning projects such as the road and railway track along the Ariankavu Pass and the Kunaun-Chilla power channel, projects that caused the fragmentation of elephant habitat. Nobody in India should be blamed for having allowed such developmental projects to fragment wildlife habitats because, unlike in Sri Lanka, the concept of corridors had not been considered. Sadly, however, even now we allow crucial wildlife corridors to be destroyed by developmental activities. The Kallar-Jaccanari corridor, for example, was identified in the early 1980s (Davidar, 1982), yet the Forest Department, which is responsible for wildlife conservation, and the institutions conducting elephant research in the area failed to work together to give this corridor a higher level of protection. Similarly, despite our increased understanding of the consequences of fragmentation, a mining project was almost sanctioned in the Siju-Rewak corridor area. Therefore, it is not only essential for Asian nations wanting to conserve their elephant populations to identify crucial corridors or habitats for elephants, they must, with intra-agency co-operative efforts, accord corridors higher protection status as wildlife sanctuaries.

Irrigation projects, industries, mining, roads and railways, human habitation and army camps are some of the development activities that have impeded and still hinder the movement of elephants. The problems faced when trying to conserve crucial corridors or other habitats should be solved as early as possible. Prolonging a threat to conservation, such as the resettlement of villagers from the crucial Chilla-Motichur corridor area, will only make the problem less tractable as the days go by. It is our belief that wildlife managers, in association with researchers, should use information technology and Geographical Information Systems (GIS) to improve their understanding and management of the areas under their jurisdiction. We also strongly advocate the immediate acquisition of land not under
Table 1 Percentage forest cover and human population density in some elephant range states

\begin{tabular}{lll}
\hline & $\begin{array}{l}\text { Forest cover, per cent } \\
\text { Country/region }\end{array}$ & $\begin{array}{l}\text { Human density } \\
\text { sq km) }\end{array}$ \\
& $15(\mathbf{1 4 4}, 000)$ & \\
\hline Bangladesh & $66(176,520)$ & 870.4 \\
Cambodia & $61(1,811,570)$ & 58.1 \\
Indonesia & $35(230,800)$ & 109.1 \\
Laos & $62(328,550)$ & 21.2 \\
Malaysia & $49(657,550)$ & 61.3 \\
Myanmar & $32(65,610)$ & 70.8 \\
Sri Lanka & $26(512,890)$ & 285.3 \\
Thailand & $30(325,490)$ & 115.1 \\
Vietnam & & 229.0 \\
\hline
\end{tabular}

Source: The World Fact Book (1994).

the jurisdiction of the Forest Department. This will avoid another critical situation like that of the Chilla-Motichur corridor area.

Many Asian countries with elephant populations are today experiencing a sudden increase in developmental activities. Data on human population densities and the area under forest cover for other elephant range countries (Table 1) suggest that large conservation units for elephants may be possible only in Cambodia, Malaysia and Myanmar. Even these countries are beset by several problems. Cambodia, for example, has the problems of land mines, civil war, shifting cultivation and poaching. Furthermore, there may be several proposals for massive developmental projects that could fragment existing wildlife habitats. Developmental activities such as roads, industries and educational institutions are necessary for any country wanting to improve the standard of living of its people. However, these countries must try to balance their developmental goals with their wildlife conservation objectives. When planning such developmental projects, enough care should be taken to ensure that species' ranges are not fragmented. Therefore, it is necessary for every country to have master plans that detail possible developmental activities in and around existing wildlife habitats and that make provision for large protected areas. In order to implement these plans regular communication is required between a nation's development planners and its conservation agencies. This alone could lead to better prospects for the larger mammals that depend solely on humans to ensure their survival.

We should also bear in mind that Sri Lanka, despite planning habitat corridors for elephants four decades ago, is still beset with problems, which grow day by day, threatening the survival prospects of elephants. It is evident that planning corridors is not enough. It should be followed by execution of the plans, which requires economic stability and political will. 


\section{Acknowledgements}

We thank Dr Yadvendra Jhala and Dr Nima Manjrekar for commenting on earlier drafts of this paper. We thank Dr Charles Santiapillai and another referee whose comments helped in improving the paper.

\section{References}

Anon. (1959) Report of the Committee on Preservation of Wildlife. Session Paper XIX, Government Press, Ceylon.

Davidar, E.R.C. (1982) Threats to Elephant Migration. WWF Monthly Report. January 1982. WWF, Gland, Switzerland.

Diamond, J.M. (1975) The island dilemma: lessons of modern biogeographic studies for the design of natural reserves. Biological Conservation, 7, 129-146.

Johnsingh, A.J.T. (1992) Protected areas and elephant conservation in India. In The Proceedings of the Asian Elephant Specialist Group Meeting, 20-22nd May 1992, Bogor, Indonesia (compiler, Asian Elephant Conservation Centre), pp. 137-147. IUCN/SSC Asian Elephant Specialist Group.

Johnsingh, A.J.T. \& Joshua, J. (1994) Conserving Rajaji and Corbett National Parks - using the elephant as a flagship species. Oryx, 28, 135-140.

Johnsingh, A.J.T., Prasad, S.N. \& Goyal, S.P. (1990) Conservation status of the Chilla-Motichur corridor for elephant movements in Rajaji-Corbett National Park area, India. Biological Conservation, 52, 125-138.

Johnsingh, A.J.T., Sathyakumar, S. \& Sunderraj, S.F.W. (1991) Ariankavu Pass, a lost elephant corridor in South India. Environmental Conservation, 18, 368.

MacArthur, R.H. \& Wilson, E.O. (1967) The Theory of Island Biogeography. Princeton. University Press, Princeton, New Jersey.

Ramakrishnan \& Sivaganesan, N. (1997) Ecological Impact Assessment on the Development of Sachidananda Jothi Niketan School adjoining the Kallar-Jacanari in Coimbatore Forest Division, Nilgiris. Sacon, Coimbatore, India.

Rodgers, W.A. \& Panwar, H.S. (1988) Planning a Wildlife Protected Area Network in India, vol. I \& II. Wildlife Institute of India, Dehra Dun.

Singh, K.N. (1995) Asiatic elephants in Uttar Pradesh (India). Status and strategy for conservation. In $A$ Week with Elephants (eds J. C. Daniel and H. S. Datye), pp. 32-48. Bombay Natural History Society, Oxford University Press, Bombay.

Sukumar, R. (1991) The Asian Elephant: Ecology and Management. Cambrige University Press, Cambridge.
Sunderraj, S.F.W., Mishra, B.K. \& Johnsingh, A.J.T. (1995) Elephant use of the Rajaji-Corbett forest corridor, north west India. In A Week with Elephants (eds J. C. Daniel and H. S. Datye), pp. 261-269. Bombay Natural History Society, Oxford University Press, Bombay.

Williams, A.C. \& Johnsingh, A.J.T. (1997) Threatened elephant corridors in Garo hills, north east India. Gajah, 16, 61-68.

The World Fact Book (1994). Central Intelligence Agency, Washington DC.

\section{Biographical sketches}

Dr A. J. T. Johnsingh gained his MSc in Zoology from Madras Christian College in Tamil Nadu, India, in 1968 and since 1973 has been actively engaged in wildlife research and conservation. He studied the ecology and behaviour of dholes in Bandipur Tiger Reserve during 1976-79 for his doctoral dissertation. During 1980-81, with a Smithsonian Institute fellowship, he studied racoons and opossums in Front Royal, Virginia, USA. On his return to India, he worked with the Bombay Natural History Society from 1982 to 1985 , primarily training biologists in elephant research. He joined the Wildlife Institute of India (WII) in 1985, where he has conducted and supervised research on the Asiatic lion, ungulates and their habitat in Gir, grizzled giant squirrel and Nilgiri langur in Tamil Nadu, elephant and goral in Rajaji National Park, ibex in Pin Valley National Park and sloth bear and tiger in Panna Tiger Reserve. He has published in international and national journals. He is a member of the IUCN Cat, Canid, Bear, Asian Elephant and Caprinae Specialist Groups. He has taught the Smithsonian Wildlife Management Training Course in China, and has conducted training programmes for forest guards and wildlife managers in Vietnam.

A. Christy Williams has a BSc in Physics and an MSc in Ecology from Salim Ali School of Ecology, Pondicherry, Tamil Nadu. Soon after his MSc in 1993 he worked on a project to estimate the densities of large mammals in Mudumalai Wildlife Sanctuary in Tamil Nadu. In December 1993 he was part of a WII team that surveyed protected areas to identify a suitable second home for the Asiatic lion. He has been involved with elephant research since November 1994, initially studying human-elephant conflict in Meghalaya, north-east India and is currently carrying out detailed ecological studies on elephants in the RajajiCorbett National Parks for his PhD. 